The Canadian Mineralogist

Vol. 42, pp. 1117-1128 (2004)

\title{
FERROTAPIOLITE AS A PSEUDOMORPH OF STIBIOTANTALITE FROM THE LAŠTOVIČKY LEPIDOLITE PEGMATITE, CZECH REPUBLIC; AN EXAMPLE OF HYDROTHERMAL ALTERATION AT CONSTANT Ta/(Ta $+\mathrm{Nb})$
}

\author{
MiLAN NOVÁK ${ }^{\S}$ \\ Institute of Geological Sciences, Masaryk University, Kotlářská 2, CZ-611 37 Brno, Czech Republic \\ PETR ČERNÝ \\ Department of Geological Sciences, University of Manitoba, Winnipeg, Manitoba R3T 2N2, Canada
}

JAN CEMPÍREK

Department of Mineralogy and Petrography, Moravian Museum, Zelný trh 2, CZ-659 37 Brno, Czech Republic

VLADIMÍR ŠREIN

Institute of Rock Mechanics, Academy of Sciences of Czech Republic, V Holešovičkách 41, CZ-182 09 Praha, Czech Republic

JAN FILIP

Institute of Geological Sciences, Masaryk University, Kotlářská 2, CZ-611 37 Brno, Czech Republic

ABSTRACT

Dark brown porous ferrotapiolite is a dominant product of alteration in pseudomorphs after primary stibiotantalite from the lepidolite pegmatite at Laštovičky, western Moravia, Czech Republic. Two compositionally distinct varieties of ferrotapiolite were recognized, a volumetrically dominant $\mathrm{Fe}^{3+}$-rich phase and a very rare $\mathrm{Sb}$-rich phase. Niobium-rich ferrotapiolite, with up to 17.51 wt. $\% \mathrm{Nb}_{2} \mathrm{O}_{5}(0.61 \mathrm{apfu})$, is highly heterogeneous, with $\mathrm{Ta} /(\mathrm{Ta}+\mathrm{Nb})$ of 0.69 to $0.84 \mathrm{and} \mathrm{Mn} /(\mathrm{Mn}+\mathrm{Fe})$ of 0.01 to 0.05 ; $\mathrm{Fe}_{2} \mathrm{O}_{3}$ calc. $\leq 3.09$ wt. $\%$ ( $0.18 \mathrm{Fe}^{3+}$ apfu, $\sim 0.16$ to $0.22 \mathrm{Fe}^{3+}$ apfu from Mössbauer spectroscopy) in the ferrian variety, and $\mathrm{Sb}_{2} \mathrm{O}_{3}$ $\leq 9.87$ wt. $\%\left(0.34 \mathrm{Sb}^{3+} a p f u\right)$ in antimonoan variety. The unit-cell dimensions of ferrian ferrotapiolite $(4.746<a<4.757 \AA, 9.198$ $<c<9.244 \AA$ ) calculated from X-ray powder-diffraction data indicate highly variable degrees of structural order. The substitution $\mathrm{NbTa}_{-1}$ is dominant; the minor substitution $\mathrm{Fe}^{3+}{ }_{3} \mathrm{Fe}^{2+}{ }_{-2} R^{5+}{ }_{-1}$ typical of the ferrian ferrotapiolite strongly suggests the incorporation of $\mathrm{Fe}^{3+}$ at both the $A$ and the $B$ sites in ferrotapiolite, indicative of solid solution toward $\mathrm{Fe}^{3+} \mathrm{TaO}_{4}$. The substitution $\mathrm{Sb}^{3+}{ }_{3}$ $\mathrm{Fe}^{2+}{ }_{-2} R^{5+}{ }_{-1}$ in the antimonoan variety tends to an end-member composition of $\mathrm{SbTaO}_{4}$, corresponding to stibiotantalite; however, it very likely reflects microscopic relics of primary stibiotantalite in ferrotapiolite hidden below the surface of polished samples. Stibiotantalite is replaced by ferrotapiolite along irregularly distributed fractures according to the hypothetical reaction $2 \mathrm{Sb}(\mathrm{Ta}, \mathrm{Nb}) \mathrm{O}_{4}+\mathrm{Fe}(\mathrm{OH})_{2}+2 \mathrm{H}_{2} \mathrm{O}=\mathrm{Fe}(\mathrm{Ta}, \mathrm{Nb})_{2} \mathrm{O}_{6}+2 \mathrm{Sb}(\mathrm{OH})_{3}$. Such a significant Fe-enrichment (stibiotantalite versus newly formed ferrotapiolite), documented by abundant secondary ferrotapiolite at Laštovičky, is exceptional among products of secondary replacement after primary (Nb,Ta)-oxide minerals in granitic pegmatites. $\mathrm{High} \mathrm{Fe}_{2} \mathrm{O}_{3}$ in ferrotapiolite indicates high but variable $f\left(\mathrm{O}_{2}\right)$ during alteration. Values of $\mathrm{Ta} /(\mathrm{Ta}+\mathrm{Nb})$ in primary stibiotantalite and secondary ferrotapiolite are virtually equal; they suggest very low mobility of both $\mathrm{Nb}$ and $\mathrm{Ta}$. Absence of hydrothermal (fluid) fractionation of $\mathrm{Nb}$ from $\mathrm{Ta}$ in granitic pegmatites and low mobility of $\mathrm{Ta}$ and $\mathrm{Nb}$ documented here and in other studies support the importance of magmatic processes as a dominant factor in crustal fractionation of $\mathrm{Ta}$ from $\mathrm{Nb}$.

Keywords: ferrotapiolite, stibiotantalite, hydrothermal alteration, $\mathrm{Nb}$ and $\mathrm{Ta}$ fractionation, lepidolite-bearing granitic pegmatite, Laštovičky, Czech Republic.

Il Dedicated to the 75th anniversary of Professor Josef Staněk.

$\S \quad$ E-mail address: mnovak@ sci.muni.cz 
Une ferrotapiolite brun foncé et poreuse est le produit prédominant de l'altération par pseudomorphose de la stibiotantalite primaire d'une pegmatite à lépidolite de Laštovičky, en Moravie occidentale, République Tchèque. Deux variétés de ferrotapiolite sont distinguées, une riche en $\mathrm{Fe}^{3+}$ et largement prédominante, et l'autre riche en $\mathrm{Sb}$. La ferrotapiolite riche en $\mathrm{Fe}^{3+}$ et en $\mathrm{Nb}$, avec jusqu'à $17.51 \% \mathrm{de} \mathrm{Nb}_{2} \mathrm{O}_{5}$ (en poids; 0.61 apfu), est fortement hétérogène, avec $\mathrm{Ta} /(\mathrm{Ta}+\mathrm{Nb}$ ) entre 0.69 et 0.84 , et $\mathrm{Mn} /(\mathrm{Mn}+\mathrm{Fe}$ ) entre 0.01 et 0.05 ; la teneur en $\mathrm{Fe}_{2} \mathrm{O}_{3}$ calculée atteint $3.09 \%$ (poids; $0.18 \mathrm{Fe}^{3+} a p f u$, entre $\sim 0.16$ et $0.22 \mathrm{Fe}^{3+}$ apfu selon la spectroscopie de Mössbauer). La variété riche en antimoine peut atteindre $9.87 \%$ (poids; $0.34 \mathrm{Sb}^{3+}$ apfu). Les paramètres réticulaires de la ferrotapiolite riche en $\mathrm{Fe}^{3+}(4.746<a<4.757 \AA$, $9.198<c<9.244 \AA)$, calculés à partir des données en diffraction $\mathrm{X}$ (méthode des poudres) indique un degré d'ordre très variable. La substitution $\mathrm{NbTa}_{-1}$ est dominante; la substitution $\mathrm{Fe}^{3+}{ }_{3} \mathrm{Fe}^{2+}{ }_{-2} R^{5+}{ }_{-1}$ est moins importante, et semble indiquer la présence de $\mathrm{Fe}^{3+}$ aux deux sites de la structure, $A$ et $B$, et donc une solution solide vers le pôle $\mathrm{Fe}^{3+} \mathrm{TaO}_{4}$. La substitution $\mathrm{Sb}^{3+}{ }_{3} \mathrm{Fe}^{2+}{ }_{-2} R^{5+}{ }_{-1}$ dans la seconde variété pourrait exprimer une solution solide vers le pôle $\mathrm{SbTaO}_{4}$, c'est-à-dire la stibiotantalite; toutefois, il est probable que le déplacement en composition est dû à la présence de reliques microscopiques de stibiotantalite primaire dans la ferrotapiolite, cachées sous la surface des échantillons polis. La stibiotantalite est remplacée par la ferrotapiolite le long de fractures distribuées de façon irrégulière selon la réaction hypothétique $2 \mathrm{Sb}(\mathrm{Ta}, \mathrm{Nb}) \mathrm{O}_{4}+\mathrm{Fe}(\mathrm{OH})_{2}+2 \mathrm{H}_{2} \mathrm{O}=\mathrm{Fe}(\mathrm{Ta}, \mathrm{Nb})_{2} \mathrm{O}_{6}+2 \mathrm{Sb}(\mathrm{OH})_{3}$. Un tel enrichissement important en fer (stibiotantalite transformée en ferrotapiolite), documenté par la présence d'une abondance de ferrotapiolite secondaire à Laštovičky, est exceptionnelle parmi les produits du remplacement des oxydes primaires de (Nb,Ta) dans les pegmatites granitiques. Les teneurs élevées en $\mathrm{Fe}_{2} \mathrm{O}_{3}$ de la ferrotapiolite indiquent des niveaux élevés mais variables de $f\left(\mathrm{O}_{2}\right)$ au cours de l'altération. Les valeurs de $\mathrm{Ta} /(\mathrm{Ta}+\mathrm{Nb})$ dans la stibiotantalite primaire et la ferrotapiolite secondaire sont presqu'égales, ce qui fait penser que le $\mathrm{Nb}$ et le $\mathrm{Ta}$ ont une mobilité très faible. L'absence de fractionnement hydrothermal de $\mathrm{Nb}$ par rapport au Ta dans les pegmatites granitiques et la faible mobilité de $\mathrm{Ta}$ et $\mathrm{Nb}$, établie ici et dans d'autres travaux, soulignent l'importance des processus magmatiques dans le fractionnement du Ta par rapport au $\mathrm{Nb}$ dans la croûte.

(Traduit par la Rédaction)

Mots-clés: ferrotapiolite, stibiotantalite, altération hydrothermale, fractionnement du Ta par rapport au Nb, pegmatite granitique à lépidolite, Laštovičky, République Tchèque.

\section{INTRODUCTION}

Products of hydrothermal alteration of stibiotantalite include a wide spectrum of minerals such as microlite and its antimonoan, uranoan and stannian varieties, stibiomicrolite, manganotantalite, cesstibtantite, wodginite, natrotantite, alumotantite, sosedkoite, rynersonite, and fersmite (e.g., Černý \& Harris 1973, Foord \& Mrose 1978, von Knorring \& Sahama 1979, Voloshin et al. 1981, Voloshin \& Pakhomovskyi 1983, 1988, Černý \& Ercit 1985, Ercit 1986, Ercit et al. 1993, Baldwin 1989, Novák \& Černý 1998a, Novák \& Šrein 1999, Cerný et al. 2004). Secondary ferrotapiolite after stibiotantalite is only known from the lepidolite pegmatite at Laštovičky (Staněk 1973, Novák \& Černý 1998a). In addition, ferrotapiolite was described as a product of hydrothermal replacement of simpsonite from the localities Leshaia, Kola Peninsula, Russia (Voloshin et al. 1981, Voloshin \& Pakhomovskyi 1983), Tanco, Bernic Lake, Manitoba, Canada, and Alto do Giz, Minas Gerais, Brazil (Ercit 1986, Ercit et al. 1986), and as a replacement product of holtite (Voloshin \& Pakhomovskyi 1988). Secondary ferrotapiolite recrystallized from remnants of an earlier generation of tapiolite was studied by von Knorring \& Fadipe (1981) from the Bulema pegmatite, Uganda. Textural relations in the mineral assemblage involving ferrotapiolite, manganotapiolite, cassiterite, microlite and native antimony from the Tiainen pegmatite, Eräjärvi, Finland
(Lahti et al. 1983) also indicate a secondary origin of the tapiolite-series minerals.

Ferrotapiolite is a dominant product of alteration in pseudomorphs of stibiotantalite from the lepidolite pegmatite at Laštovičky, western Moravia, Czech Republic. Here we describe chemical composition, structural state and compositional relationship of ferrotapiolite to the parent stibiotantalite. This mineral assemblage seems to be confined to the system $\mathrm{Ta}_{2} \mathrm{O}_{5}-\mathrm{Nb}_{2} \mathrm{O}_{5}-$ $\mathrm{Sb}_{2} \mathrm{O}_{3}-\mathrm{Fe}_{2} \mathrm{O}_{3}-\mathrm{FeO}$. Zoned primary stibiotantalite enclosed in quartz and lepidolite is evidently suitable for the study of cation-exchange reactions between stibiotantalite and fluid to give ferrotapiolite (see Putnis 2002), mobility of the individual elements in the above system, and particularly the potential fractionation of $\mathrm{Nb}$ from Ta during the process of hydrothermal alteration (e.g., Green 1995, Linnen \& Keppler 1997).

\section{OCCURREnCE AND Paragenesis}

The Laštovičky pegmatite is situated in the northernmost part of the Bory pegmatite district, western Moravia (Fig. 1). The district comprises numerous symmetrically zoned pegmatite dikes with abundant schorl, biotite, muscovite, andalusite and sekaninaite. There are also several evolved phosphate-bearing pegmatites with primary $(\mathrm{Fe}, \mathrm{Mn})$-phosphates (triplite, zwieselite, triphylite) and the most evolved lepidolite-subtype pegmatites, Laštovičky, Dobrá Voda and Dolní Bory, 


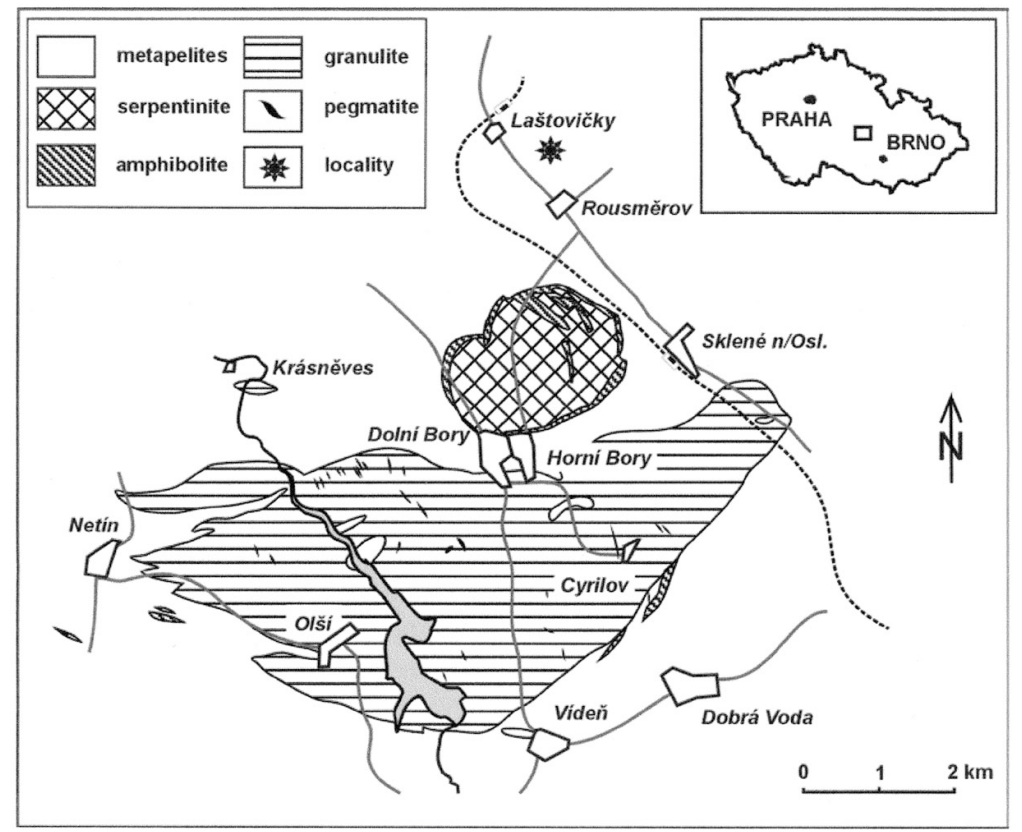

FIG. 1. Schematic geological map of the Bory pegmatite district, as modified from Duda (1986); the location of the Laštovičky pegmatite is indicated.

dike No. 21 (see Novák et al. 1992). The internal structure and mineralogy of the Laštovičky pegmatite were described by Staněk (1973), Novák \& Cerný (1998a), and Selway et al. (1999). The symmetrically zoned pegmatite dike, up to $1 \mathrm{~m}$ across, cross-cuts a biotite-sillimanite gneiss. It consists, from the contacts inward, of (i) a granitic zone $(\mathrm{Kfs}+\mathrm{Qtz}+\mathrm{Pl}+\mathrm{Ms}+\mathrm{Bt})$, (ii) a graphic zone (Kfs + Qtz) evolving to (iii) blocky K-feldspar, (iv) an albite unit (Ab + Qtz + Ms-Lpd + Srl-Elb), and (v) a lepidolite unit (Lpd + Qtz + Ab + Elb) with rare pockets, situated in the center of the dike.

Niobium-tantalum oxide minerals are represented by columbite-group minerals, stibiotantalite, ferrotapiolite and very rare stibiomicrolite (Staněk 1973, Novák \& Černý 1998a). Rare platy crystals $(<2 \mathrm{~mm})$ of ferrocolumbite-manganocolumbite with $\mathrm{Ta} /(\mathrm{Ta}+\mathrm{Nb})_{\text {at }}$. in the range 0.12 to 0.15 and $\mathrm{Mn} /(\mathrm{Mn}+\mathrm{Fe})_{\text {at. }}$ in the range 0.48 to 0.63 are closely associated with muscovite-quartz aggregates and green elbaite located in the outer part of the albite-dominant unit. A large crystal of manganocolumbite $(\sim 2 \mathrm{~cm})$ from an albite-quartz aggregate associated with lepidolite in the inner part of albite unit was described by Staněk (1973).

\section{MEthods}

Ferrotapiolite and stibiotantalite were analyzed on a Cameca Camebax SX-50 instrument in wavelength-dis- persion (WDS) mode at the Department of Geological Sciences, University of Manitoba, Winnipeg: a beam diameter of 1-2 $\mu \mathrm{m}$, an accelerating potential of $15 \mathrm{kV}$, a sample current of $20 \mathrm{~mA}$ and a counting time of $20 \mathrm{~s}$ were used for $\mathrm{Ca}, \mathrm{Nb}$, and $\mathrm{Ta} ; 40 \mathrm{~mA}$ and $50 \mathrm{~s}$ were used for $\mathrm{Ba}, \mathrm{Fe}, \mathrm{Mn}, \mathrm{Pb}, \mathrm{Sb}, \mathrm{Bi}, \mathrm{Sn}, \mathrm{Ti}, \mathrm{U}, \mathrm{Si}$, and $\mathrm{W}$. The following standards were used: manganotantalite $(\mathrm{Ta} M \alpha), \mathrm{MnNb}_{2} \mathrm{O}_{6}(\mathrm{Mn} K \alpha, \mathrm{Nb} L \alpha), \mathrm{FeNb}_{2} \mathrm{O}_{6}(\mathrm{Fe} K \alpha)$, $\mathrm{CaNb}_{2} \mathrm{O}_{6}(\mathrm{CaK} \alpha), \mathrm{SnO}_{2}(\mathrm{Sn} L \alpha)$, quartz $(\mathrm{Si} K \alpha)$, rutile $(\mathrm{Ti} K \alpha), \mathrm{BiTaO}_{4}(\mathrm{Bi} M \alpha)$, mimetite $(\mathrm{Pb} M \alpha)$, stibiotantalite $(\mathrm{Sb} L \alpha), \mathrm{UO}_{2}(\mathrm{U} M \alpha), \mathrm{Ba}_{2} \mathrm{NaNb}_{5} \mathrm{O}_{15}(\mathrm{Ba} L \alpha)$ and metallic $\mathrm{W}(\mathrm{W} M \alpha)$. The data were reduced using the PAP routine of Pouchou \& Pichoir $(1984,1985)$. Some of the chemical analyses were performed on a JEOL JXA-50 electron microprobe at the Geological Institute of Academy of Sciences, Prague, operating in a WDS mode, at an accelerating potential of $20 \mathrm{kV}$ and a specimen current of 1.5 to $3.0 \mathrm{nA}$. The following standards were used: ferberite (WM $\mathrm{W})$, metallic Ta $(\mathrm{Ta} M \alpha)$, $\mathrm{LiNbO}_{3}(\mathrm{Nb} L \alpha)$, cassiterite $(\mathrm{Sn} L \alpha), \mathrm{TiO}_{2}(\mathrm{TiK} \alpha), \mathrm{ZrO}_{2}$ $(\mathrm{Zr} L \alpha), \mathrm{SiO}_{2}(\mathrm{Si} K \alpha)$, metallic $\mathrm{Sc}(\mathrm{Sc} K \alpha)$, metallic $\mathrm{Sb}$ $(\mathrm{Sb} L \alpha), \mathrm{Fe}_{2} \mathrm{O}_{3}(\mathrm{Fe} K \alpha), \mathrm{Mn}_{3} \mathrm{O}_{4}(\mathrm{Mn} K \alpha)$, apatite $(\mathrm{Ca} K \alpha)$, pyroxene $(\mathrm{CaK} \alpha)$. The data were reduced using $\mathrm{ZAF}$ corrections. Normalization on three cations and six atoms of oxygen per formula unit was used for calculation of $\mathrm{Fe}^{3+}$ in ferrotapiolite. 
${ }^{57} \mathrm{Fe}$ Mössbauer spectroscopy was carried out at the Institute of Physics of Materials, Academy of Sciences, Brno, Czech Republic. Mössbauer spectra of tapiolite were collected at room temperature (RT MS) in transmission geometry using ${ }^{57} \mathrm{Co}$ in a $\mathrm{Rh}$ source with a 1024-register multichannel analyzer. The spectrum was processed using a standard package of computer programs by a least-squares procedure assuming Lorentzian line shapes constrained to equal linewidths. Results (isomer shift $\delta$ and quadrupole splitting $\sigma$ ) were calibrated with an $\alpha$-Fe foil. Ferrotapiolite is a strong gamma-ray absorber because of its high Ta content. Thus it was not possible to work with an ideal thickness of sample to obtain high-quality spectra, because the amount of available material was limited and its texture is porous (with potential relics of stibiotantalite).

$\mathrm{X}$-ray powder-diffraction data were obtained on a computer-controlled X-ray diffractometer Stadi-P (Stoe $\& \mathrm{Cie}$ Gmbh) in transmission mode, with $\mathrm{CoK} \alpha_{1}$ radiation [with a Ge (111) monochromator], externally calibrated with Si (NBS 640b) and position-sensitive detector at the Institute of Geological Sciences, Masaryk University, Brno. The diffraction patterns were evaluated and unit-cell dimensions were refined using the Stoe WinXPow software package. The porosity of the ferrotapiolite was measured from BSE images of the polished surface; the software SigmaScan Pro was used for image analysis.

\section{Results}

\section{Description of stibiotantalite and ferrotapiolite}

Bright yellow stibiotantalite forms irregular grains and loose fragments of crystals, up to $8 \mathrm{~mm}$ in size, all showing a good cleavage. It is commonly found in debris inside the pockets. Stibiotantalite is associated with quartz, pink elbaite to rossmanite, and pale violet trilithionite, but its paragenetic position among the pocket minerals is not clear (Staněk 1973). It contains very rare, tiny inclusions of native antimony $(\leq 2 \mu \mathrm{m})$. Subhedral grains of stibiotantalite $(\leq 3 \mathrm{~mm})$ also are enclosed in massive quartz and in coarse flakes of lepidolite located close to the pockets.

Stibiotantalite is replaced along irregularly developed fractures by dark brown, porous ferrotapiolite (Fig. 2 ). The measured porosity varies from $28 \mathrm{vol} \%$ in fresh portions to $\sim 50 \%$ in relatively weathered portions of ferrotapiolite, where pores were commonly filled by late hydrothermal clay minerals (possibly montmorillonite and cookeite; Fig. 2). The ferrotapiolite may volumetrically predominate over primary stibiotantalite, but no ferrotapiolite or other $(\mathrm{Nb}, \mathrm{Ta})$-oxide minerals were observed outside the replaced stibiotantalite grains. The observed sequence of replacement is: stibiotantalite (with small inclusions of native antimony) $\rightarrow$ very rare stibiomicrolite (with small inclusions of cesstibtantite) $\rightarrow$ ferrotapiolite. The sequence is similar to that observed in the Dobrá Voda pegmatite, located in the Bory pegmatite district (Novák \& Černý 1998a, Novák \& Staněk 1999).

On the basis of chemical composition, we recognized two compositionally distinct varieties of ferrotapiolite at Laštovičky: a volumetrically dominant ferrian variety and a very rare $\mathrm{Sb}$-rich variety. The latter variety forms small, irregular areas $(\leq 50 \mu \mathrm{m})$, brighter in the BSE image than the ferrian variety. The measured porosity and a large part of chemical compositions presented here pertain to the volumetrically dominant ferrian variety; Mössbauer spectra and X-ray-diffraction
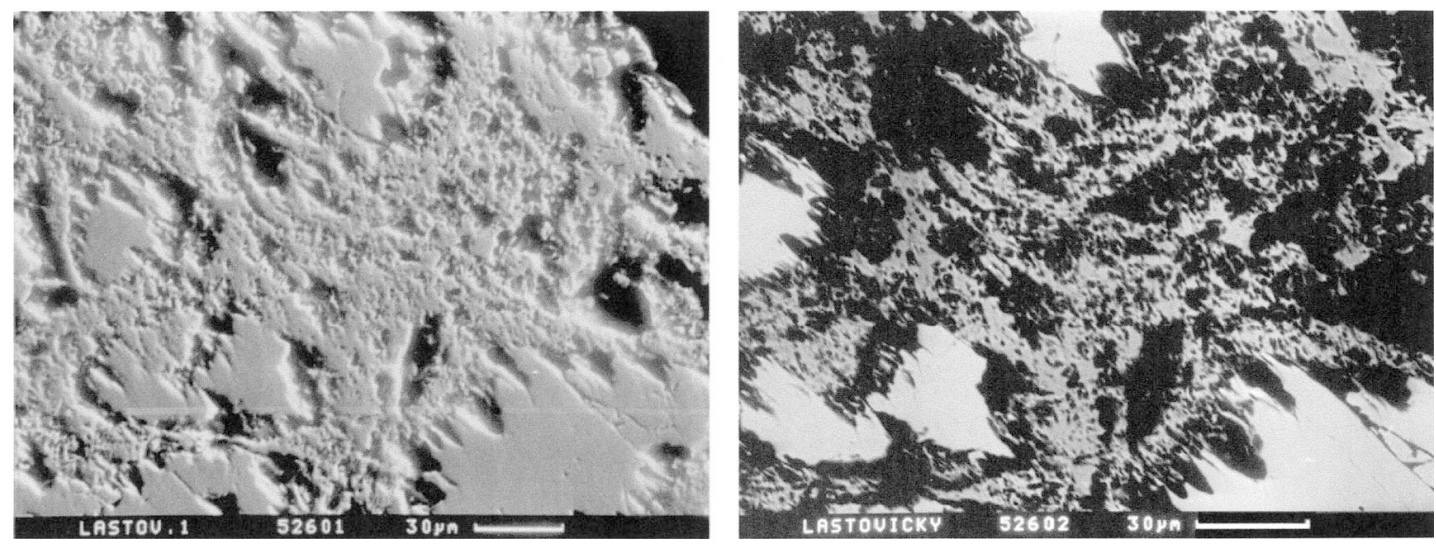

FIG. 2. SEM (a) and BSE (b) images of primary stibiotantalite (bright in BSE) and secondary $\mathrm{Fe}^{3+}$-rich ferrotapiolite (grey in BSE). Note the high porosity of the ferrotapiolite; pores (black in BSE) are commonly filled by clay minerals. 
data had to be unavoidably collected on mixtures with variable proportions of the two varieties; however, the ferrian variety very likely predominated in all samples.

\section{Chemical composition, Mössbauer spectroscopy and X-ray powder diffraction}

Primary stibiotantalite exhibits significant zoning in terms of $\mathrm{Ta} /(\mathrm{Ta}+\mathrm{Nb})$, which ranges from 0.67 to 0.92 from core to rim (Table 1). Minor elements include $\mathrm{Sn}$ $\left(\leq 0.67\right.$ wt. $\left.\% \mathrm{SnO}_{2}\right)$ and $\mathrm{W}\left(\leq 0.55\right.$ wt. $\left.\% \mathrm{WO}_{3}\right)$. Other elements such as $\mathrm{Ti}, \mathrm{Bi}, \mathrm{U}, \mathrm{Pb}, \mathrm{Fe}$ and $\mathrm{Mn}$ were mostly detected in minor quantities close to or below their detection limits.

Ferrotapiolite is highly heterogeneous in $\mathrm{Ta} /(\mathrm{Ta}+$ $\mathrm{Nb}$ ), from 0.69 to 0.84 , and it has a very high $\mathrm{Nb}$ content, up to 0.61 apfu (Table 1). Most of the $\mathrm{Ta} /(\mathrm{Ta}+$ $\mathrm{Nb}$ ) values are tightly clustered, but a single composition with 0.61 apfu $\mathrm{Nb}$ surpassed the highest $\mathrm{Nb}$ content recorded to date in the minerals of the tapiolite series (as reviewed by Wise \& Černý 1996). Values of $\mathrm{Mn} /(\mathrm{Mn}+\mathrm{Fe})$ are very low, from 0.01 to 0.05 . Concentrations of minor elements in both compositional types of ferrotapiolite include $\mathrm{W}\left(\leq 1.61\right.$ wt. $\left.\% \mathrm{WO}_{3}\right), \mathrm{Mn}$ $(\leq 0.76 \% \mathrm{MnO})$, $\mathrm{Ti}\left(\leq 0.28 \% \mathrm{TiO}_{2}\right), \mathrm{Ca}(\leq 0.13 \% \mathrm{CaO})$, $\mathrm{Fe}\left(\leq 3.09 \% \mathrm{Fe}_{2} \mathrm{O}_{3 \text { calc }} ; 0.18\right.$ apfu $\left.\mathrm{Fe}^{3+}\right)$ in the ferrian variety, and particularly $\mathrm{Sb}\left(\leq 9.87 \% \mathrm{Sb}_{2} \mathrm{O}_{3} ; 0.34\right.$ apfu $\mathrm{Sb}^{3+}$ ) in the antimonoan variety.

In order to verify our calculation of $\mathrm{Fe}^{3+}$ content from stoichiometry, we performed measurements on Mössbauer spectra. The representative room-temperature spectra of ferrian ferrotapiolite (Fig. 3) are characterized by two absorption maxima showing a predominance of $\mathrm{Fe}^{2+}$; complex absorption overlaps occur near the $\mathrm{Fe}^{3+}$ quadrupole envelopes. All samples thus were fitted to three quadrupole doublets with ${ }^{57} \mathrm{Fe}$ hyperfine parameters characteristic of high-spin $\mathrm{Fe}^{2+}$ in octahedral coordination. Hyperfine parameters are: $\delta=$ $1.10(1), 1.06(1)$ and $1.14(2) \mathrm{mm} / \mathrm{s}$ and $\sigma=3.02(1)$, $2.52(1)$ and $1.85(2) \mathrm{mm} / \mathrm{s}$, respectively. Hyperfine parameters are similar to those presented by Kinast et al. (2002). At least three additional doublets of $\mathrm{Fe}^{3+}$ in octahedral coordination could be fitted, but their hyperfine parameters vary, depending on the specific fit model (more fit models are possible owing to complex overlaps within the range 0 to $1.5 \mathrm{~mm} / \mathrm{s}$ of the spectra and low Mössbauer response of our samples). Hyperfine parameters of $\mathrm{Fe}^{3+}$ for the best-fit model are: $\delta=$ $0.20,0.40$ and $0.50 \mathrm{~mm} / \mathrm{s}$ and $\sigma=0.43,0.62$ and 1.04 , respectively (the latter doublet seems to represent charge balance between $\mathrm{Fe}^{2+}$ and $\mathrm{Fe}^{3+}$ ). For ferrian ferrotapiolite, the proportion of $\mathrm{Fe}^{3+}$ varies from 16 to $22 \%$ of the total $\mathrm{Fe}$, depending on fit model used for solution of any given spectrum. Thus the calculated and Mössbauer-determined contents of $\mathrm{Fe}^{3+}$ are in mutual agreement, confirming the general validity of the stoichiometric calculation introduced by Ercit (1986). However, we prefer the values calculated from stoichi- ometry for crystal-chemical discussion, because of the ambiguities involved in interpreting our Mössbauer spectra.

The structural formula of ferrotapiolite (Table 1) varies between ${ }^{A}\left(\mathrm{Fe}^{2+}{ }_{0.93} \mathrm{Fe}^{3+}{ }_{0.04} \mathrm{Mn}_{0.03}\right)_{\Sigma 1.00}{ }^{B}\left(\mathrm{Ta}_{1.57} \mathrm{Nb}_{0.38}\right.$ $\left.\mathrm{W}_{0.02} \mathrm{Sn}^{4+}{ }_{0.01} \mathrm{Fe}^{3+}{ }_{0.02}\right)_{\Sigma 2.00} \mathrm{O}_{6.00}$ and ${ }^{A}\left(\mathrm{Fe}^{2+}{ }_{0.85} \mathrm{Fe}^{3+}{ }_{0.12}\right.$ $\left.\mathrm{Mn}_{0.02}\right)_{\Sigma 1.00}{ }^{B}\left(\mathrm{Ta}_{1.52} \mathrm{Nb}_{0.39} \mathrm{~W}_{0.01} \mathrm{Sn}^{4+}{ }_{0.01} \mathrm{Fe}^{3+}{ }_{0.06}\right)_{\Sigma 2.00} \mathrm{O}_{6.00}$ for $\mathrm{Sb}$-free ferrotapiolite, and between ${ }^{A}\left(\mathrm{Fe}^{2+}{ }_{0.90}\right.$ $\left.\mathrm{Sb}^{3+}{ }_{0.07} \mathrm{Mn}_{0.01}\right)_{\Sigma 1.01}{ }^{B}\left(\mathrm{Ta}_{1.63} \mathrm{Nb}_{0.33} \mathrm{~W}_{0.01} \mathrm{Sn}^{4+}{ }_{0.02}\right)_{\Sigma 1.99} \mathrm{O}_{6.02}$ and ${ }^{A}\left(\mathrm{Fe}^{2+}{ }_{0.83} \mathrm{Sb}^{3+}{ }_{0.21} \mathrm{Mn}_{0.01}\right)_{\Sigma 1.05}{ }^{B}\left(\mathrm{Ta}_{1.56} \mathrm{Nb}_{0.35}\right.$ $\left.\mathrm{W}_{0.01} \mathrm{Sn}^{4+}{ }_{0.02}\right)_{\Sigma 1.95} \mathrm{O}_{6.01}$, locally ${ }^{A}\left(\mathrm{Fe}^{2+}{ }_{0.73} \mathrm{Sb}^{3+}{ }_{0.34}\right.$ $\left.\mathrm{Mn}_{0.01}\right)_{\Sigma 1.08}{ }^{B}\left(\mathrm{Ta}_{1.53} \mathrm{Nb}_{0.35} \mathrm{~W}_{0.01} \mathrm{Sn}^{4+}{ }_{0.03}\right)_{\Sigma 1.92} \mathrm{O}_{6.04}$ for antimonoan ferrotapiolite, respectively.

Unit-cell dimensions of the secondary ferrotapiolite were calculated from X-ray powder-diffraction records (Table 2). The samples studied yielded one of three

TABLE 1. CHEMICAL COMPOSITIONS OF THE LAŠTOVICKY STIBIOTANTALITE (SB SERIES) AND FERROTAPIOLITE (OTHERS)

$\begin{array}{llllllllll}\mathrm{SB} & \mathrm{SB} & \mathrm{SB} & 3104 & 16 & 16 & 17 & 15 & 15 & 3\end{array}$

$$
\text { TA2 TA4 TA5 TAP TAP TAP TAP TAP }
$$


$\begin{array}{lllllllllll}\mathrm{Nb}_{2} \mathrm{O}_{5} & 12.80 & 5.63 & 3.90 & 17.5 & 10.40 & 10.10 & 10.80 & 9.06 & 9.57 & 9.41\end{array}$ $\begin{array}{lllllllllll}\mathrm{Ta}_{2} \mathrm{O}_{5} & 40.90 & 52.60 & 53.70 & 66.3 & 70.60 & 71.10 & 69.30 & 70.20 & 70.10 & 67.75\end{array}$ $\begin{array}{lllllllllll}\mathrm{TiO}_{2} & 0.02 & 0.03 & 0.02 & 0.28 & 0.01 & 0.04 & 0.01 & 0.04 & 0.02 & 0.02\end{array}$ $\begin{array}{lllllllllll}\mathrm{TiO}_{2} & 0.02 & 0.03 & 0.02 & 0.28 & 0.01 & 0.04 & 0.01 & 0.04 & 0.02 & 0.02 \\ \mathrm{SiO}_{2} & 0.00 & 0.00 & 0.00 & 0 & 0.01 & 0.00 & 0.00 & 0.05 & 0.02 & 0.04\end{array}$ $\begin{array}{lllllllllll}\mathrm{SiO}_{2} & 0.00 & 0.00 & 0.00 & 0 & 0.01 & 0.00 & 0.00 & 0.05 & 0.02 & 0.04 \\ \mathrm{SnO}_{2} & 0.53 & 0.80 & 0.67 & 0.00 & 0.15 & 0.59 & 0.42 & 0.67 & 0.75 & 0.80\end{array}$ $\begin{array}{lllllllllll}\mathrm{UO}_{2} & 0.08 & 0.00 & 0.00 & 0.00 & 0.00 & 0.00 & 0.07 & 0.00 & 0.13 & 0.03\end{array}$ $\begin{array}{llllllllllll}\mathrm{Sb}_{2} \mathrm{O}_{3} & 43.00 & 40.10 & 40.60 & 0.1 & 0.04 & 0.04 & 0.00 & 4.13 & 6.12 & 9.87\end{array}$ $\begin{array}{lllllllllll}\mathrm{Bi}_{2} \mathrm{O}_{3} & 0.00 & 0.00 & 0.37 & 0 & 0.05 & 0.03 & 0.00 & 0.11 & 0.02 & 0.06\end{array}$

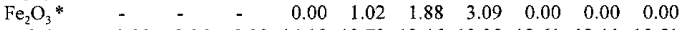
$\begin{array}{lllllllllll}\mathrm{FeO}^{*} & 0.00 & 0.06 & 0.00 & 14.19 & 13.72 & 13.46 & 13.05 & 12.61 & 12.11 & 10.51\end{array}$ $\begin{array}{lllllllllll}\mathrm{MnO} & 0.01 & 0.00 & 0.00 & 0.76 & 0.38 & 0.27 & 0.33 & 0.21 & 0.20 & 0.17\end{array}$ $\begin{array}{lllllllllll}\mathrm{MnO} & 0.01 & 0.00 & 0.00 & 0.76 & 0.38 & 0.27 & 0.33 & 0.21 & 0.20 & 0.17 \\ \mathrm{CaO} & 0.00 & 0.00 & 0.00 & 0.13 & 0.00 & 0.05 & 0.04 & 0.01 & 0.04 & 0.00\end{array}$ $\begin{array}{llllllllllll}\mathrm{CaO} & 0.00 & 0.00 & 0.00 & 0.13 & 0.00 & 0.05 & 0.04 & 0.01 & 0.04 & 0.00 \\ \mathrm{BaO} & 0.00 & 0.11 & 0.19 & 0.00 & 0.14 & 0.01 & 0.02 & 0.08 & 0.03 & 0.00\end{array}$ $\begin{array}{lllllllllll}\mathrm{PbO} & 0.00 & 0.00 & 0.00 & 0.00 & 0.13 & 0.31 & 0.00 & 0.15 & 0.00 & 0.05\end{array}$

$\begin{array}{llllllll}\text { Total } \quad 97.79 & 99.69100 .00100 .86 & 97.48 & 98.54 & 97.71 & 98.03 & 99.55 & 99.05\end{array}$ $\begin{array}{lllllllllll}\mathrm{W}^{6+} \text { apfu } & 0.007 & 0.005 & 0.008 & 0.032 & 0.018 & 0.014 & 0.012 & 0.015 & 0.009 & 0.007 \\ \mathrm{Nb}^{5+} & 0.332 & 0.150 & 0.105 & 0.605 & 0.384 & 0.368 & 0.393 & 0.339 & 0.353 & 0.353\end{array}$ $\begin{array}{llllllllllllll}\mathrm{Nb}^{\mathrm{s}^{*}} & 0.332 & 0.150 & 0.105 & 0.605 & 0.384 & 0.368 & 0.393 & 0.339 & 0.353 & 0.353 \\ \mathrm{~T}^{\mathrm{s}^{*}} & & 0.638 & 0.842 & 0.869 & 1.377 & 1.567 & 1.561 & 1.517 & 1.580 & 1.558 & 1.529\end{array}$

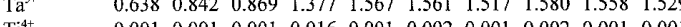


$\begin{array}{llllllllllll}\mathrm{Si}^{4+} & & 0.000 & 0.000 & 0.000 & 0.000 & 0.001 & 0.000 & 0.000 & 0.004 & 0.002 & 0.003\end{array}$ $\begin{array}{lllllllllllll}\mathrm{Sn}^{4+} & 0.012 & 0.019 & 0.016 & 0.000 & 0.005 & 0.019 & 0.013 & 0.022 & 0.024 & 0.026\end{array}$ $\begin{array}{llllllllllll}{ }^{3} \mathrm{Fe}^{3+} & - & - & - & 0.000 & 0.024 & 0.036 & 0.064 & 0.000 & 0.000 & 0.000\end{array}$ $\begin{array}{llllllllllll}\Sigma B \text { site } & 0.990 & 1.018 & 0.999 & 2.030 & 2.000 & 2.000 & 2.000 & 1.962 & 1.947 & 1.919\end{array}$ $\begin{array}{llllllllllll}\mathrm{U}^{\text {4+ }} & 0.001 & 0.000 & 0.000 & 0.000 & 0.000 & 0.000 & 0.001 & 0.000 & 0.002 & 0.001\end{array}$ $\begin{array}{llllllllllllll}\mathrm{Bi}^{3+} & 0.000 & 0.000 & 0.006 & 0.000 & 0.001 & 0.001 & 0.000 & 0.002 & 0.000 & 0.001\end{array}$

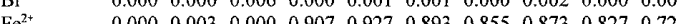


$\begin{array}{llllllllllllll}\mathrm{re}^{\mathrm{Fe}} & & 0.000 & 0.000 & 0.000 & 0.000 & 0.038 & 0.076 & 0.118 & 0.000 & 0.000 & 0.000 \\ \mathrm{Sb}^{3+} & & 1.017 & 0.974 & 0.996 & 0.003 & 0.001 & 0.001 & 0.000 & 0.141 & 0.206 & 0.337\end{array}$ $\begin{array}{llllllllllll}\mathrm{Sb}^{3+} & & 1.017 & 0.974 & 0.996 & 0.003 & 0.001 & 0.001 & 0.000 & 0.141 & 0.206 & 0.337 \\ \mathrm{Mn}^{2+} & & 0.000 & 0.000 & 0.000 & 0.049 & 0.026 & 0.018 & 0.022 & 0.015 & 0.014 & 0.012\end{array}$ $\begin{array}{llllllllllll}\mathrm{Ca}^{2} & 0.000 & 0.000 & 0.000 & 0.011 & 0.000 & 0.004 & 0.003 & 0.001 & 0.003 & 0.000\end{array}$ $\begin{array}{lllllllllll}\mathrm{Ba}^{2+} & 0.000 & 0.003 & 0.004 & 0.000 & 0.004 & 0.000 & 0.001 & 0.003 & 0.001 & 0.000\end{array}$ $\begin{array}{lllllllllllll}\mathrm{Pb}^{2+} & & 0.000 & 0.000 & 0.000 & 0.000 & 0.003 & 0.007 & 0.000 & 0.003 & 0.000 & 0.001\end{array}$

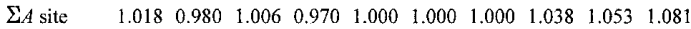

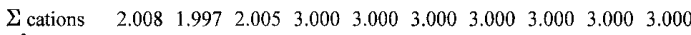
$\begin{array}{llllllllllll}\mathrm{O}^{2-} & 4.000 & 4.000 & 4.000 & 6.055 & 6.000 & 6.000 & 6.000 & 6.012 & 6.014 & 6.038\end{array}$ $\begin{array}{llllllllllllll}\mathrm{Fe}^{2+} / \mathrm{Fe}_{\mathrm{tot}} & - & 1.000 & - & 1.000 & 0.937 & 0.889 & 0.824 & 1.000 & 1.000 & 1.000\end{array}$

* The ratio $\mathrm{Fe}^{2+} / \mathrm{Fe}^{3+}$ was calculated on the basis of a charge-balanced formula. $\mathrm{Na}, \mathrm{K}, \mathrm{Cs}$, and $\mathrm{F}$ are below the detection limit. 
distinct patterns with different degrees of order and differences in apparent content of $\mathrm{Fe}^{3+}$ (Fig. 4). Concentrations of $\mathrm{W}, \mathrm{Ti}$ and $\mathrm{Sn}$ are generally very low, thus the content of $\mathrm{Fe}^{3+}$ may be correlated with variations of cation order. However, the structural features do not seem to be simply related to fluctuations in the chemical composition ( $c f$. discussion in Wise \& Černý 1996).

\section{DISCUSSION}

Chemical composition and mechanisms of substitution

Values of $\mathrm{Mn} /(\mathrm{Mn}+\mathrm{Fe})$ in ferrotapiolite are very low (Fig. 5) and comparable to those in ferrotapiolite from less fractionated granitic pegmatites (Černý et al. 1992) and rare-metal granites (Wang et al. 1997). The volumetrically dominant ferrian variety contains $\mathrm{Fe}^{3+}$ concentrations, calculated from stoichiometry and confirmed by Mössbauer spectroscopy to be as high as 0.21 $a p f u$. The dominant substitution $\mathrm{NbTa}_{-1}$ and the minor substitution $\mathrm{Fe}^{3+}{ }_{3} \mathrm{Fe}^{2+}{ }_{2} R^{5+}{ }_{-1}$, which relates end-member ferrotapiolite component $\left(\mathrm{Fe}^{2+} \mathrm{Ta}_{2} \mathrm{O}_{6}\right)$ to a hypothetical rutile-structured $\mathrm{Fe}^{3+} \mathrm{TaO}_{4}$ component, are inferred. The latter substitution derived from negative correlations $\mathrm{W}+\mathrm{Nb}+\mathrm{Ta}$ versus $\mathrm{Fe}^{3+}$ and $\mathrm{Fe}^{2+}+\mathrm{Mn}$ versus $\mathrm{Fe}^{3+}$ (Fig. 6) is not mentioned by Wise \& Černý (1996). It implies incorporation of $\mathrm{Fe}^{3+}$ at both $A$ and $B$ sites in the ferrotapiolite structure.
The complicated Mössbauer spectrum of the sample studied indicates a disordered structure with most $\mathrm{Fe}^{2+}$ in $\mathrm{FeO}_{6}$ octahedra, and with the $\mathrm{Fe}^{3+}$ probably split between the $\mathrm{FeO}_{6}$ and $\mathrm{TaO}_{6}$ octahedra, or a domain structure with short-ordered domains of ferrotapiolite but without long-range continuity in terms of cation order. Different $\mathrm{Fe}^{2+}$ doublets could result from disorder at one site, where a particular atom of Fe could be surrounded by different cations in second coordination shell (nextnearest-neighbor effect), or it could also suggest incorporation of part of $\mathrm{Fe}^{2+}$ into the $\mathrm{TaO}_{6}$ octahedra. The Mössbauer spectra of ferrotapiolite crystals from Laštovičky were certainly influenced by the highly het-

\begin{tabular}{lccc}
\multicolumn{4}{c}{$\begin{array}{c}\text { TABLE 2. UNIT-CELL DIMENSIONS OF FERROTAPIOLITE } \\
\text { FROM THE LAŠTOVIČKY PEGMATITE }\end{array}$} \\
\hline Sample & $a(\AA)$ & $c(\AA)$ & $V\left(\AA^{3}\right)$ \\
\hline & & & \\
Las1a & $4.7506(7)$ & $9.2412(21)$ & $208.56(5)$ \\
Las1b & $4.7500(7)$ & $9.2443(17)$ & $208.57(4)$ \\
Las2 & $4.7575(4)$ & $9.2213(10)$ & $208.72(2)$ \\
Las3 & $4.7567(4)$ & $9.2198(11)$ & $208.61(3)$ \\
Las5* & $4.7579(6)$ & $9.2267(18)$ & $208.87(5)$ \\
Las6* & $4.7459(3)$ & $9.1976(10)$ & $207.17(3)$ \\
Las7 & $4.7459(3)$ & $9.2013(12)$ & $207.25(3)$ \\
Las8 & $4.7457(5)$ & $9.1986(15)$ & $207.17(4)$ \\
& & &
\end{tabular}

* Refined from mixture with stibiotantalite.

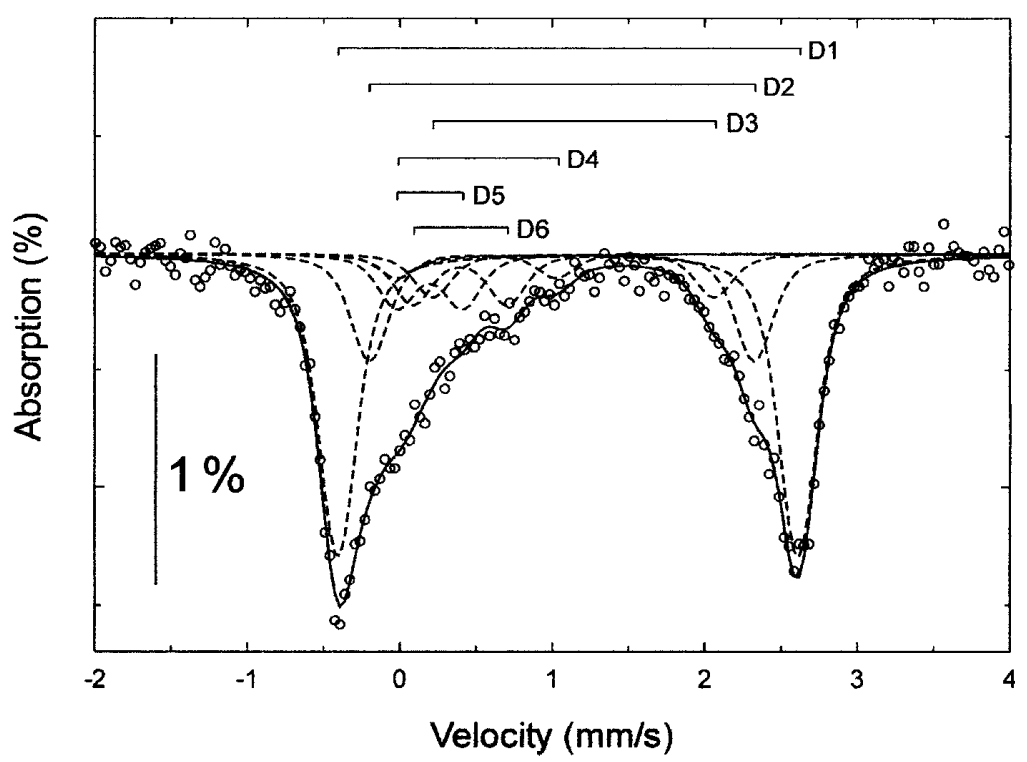

FIG. 3. Representative ${ }^{57} \mathrm{Fe}$ Mössbauer spectrum of $\mathrm{Fe}^{3+}$-rich ferrotapiolite, obtained at room temperature. Open circles: observed data; solid line: the calculated spectrum based on least-squares procedure; dashed lines: the calculated subspectra. D1-D3: $\mathrm{Fe}^{2+}$ in octahedral coordinations; D4-D6: $\mathrm{Fe}^{3+}$ in octahedral coordinations (D4 could represent charge-balanced iron). 




FIG. 4. The $a$ and $c$ unit-cell dimensions of the Laštovičky ferrotapiolite in the grid of Wise \& Cerný (1996).

erogeneous character of the samples studied, with variable $\mathrm{Ta} /(\mathrm{Ta}+\mathrm{Nb})$ values, distinct unit-cell dimensions and degree of structural order, as well as likely contamination by included minerals, as well as potential weathering.

The EMP analyses of the very rare antimonoan variety yielded up to 9.87 wt. $\% \mathrm{Sb}_{2} \mathrm{O}_{3}(0.34$ apfu $\mathrm{Sb})$, by far the highest content of $\mathrm{Sb}$ recorded in ferrotapiolite ( $c f$. Wise \& Černý 1996, Novák \& Černý 1998a); however, the valence state of $\mathrm{Sb}$ is not clear. Nevertheless, the presence of $\mathrm{Sb}^{5+}$ in the ferrotapiolite structure, as was found in a rutile-type-structure mineral tripuhyite $\mathrm{Fe}^{3+} \mathrm{Sb}^{5+} \mathrm{O}_{4}$ (Berlepsch et al. 2003), is not likely owing to the sum of anions higher than ideal 6 apfu. Assuming the presence of $\mathrm{Sb}^{3+}$ in the ferrotapiolite structure, the negative correlations $\mathrm{Nb}+\mathrm{Ta}+$ W versus $\mathrm{Sb}^{3+}$ and $\mathrm{Fe}^{2+}$ $+\mathrm{Mn}$ versus $\mathrm{Sb}^{3+}$ (Fig. 6) suggest the substitution $\mathrm{Sb}^{3+}{ }_{3} \mathrm{Fe}^{2+}{ }_{-2} R^{5+}{ }_{-1}$. Such a mechanism of substitution leads to the end-member composition $\mathrm{SbTaO}_{4}$.

It is noteworthy that ferrotapiolite with the second highest $\mathrm{Sb}$ content $\left(1.20 \mathrm{wt} . \% \mathrm{Sb}_{2} \mathrm{O}_{3}\right.$, found in a single analyzed spot), from the Tiainen pegmatite, in Finland, contains numerous microscopic inclusions of native antimony (Lahti et al. 1983). Consequently, the presence of microscopic inclusions of Sb-rich minerals in ferrotapiolite (native antimony at the Tiainen pegmatite, relics of stibiotantalite at Laštovičky), the nonexistence of $\mathrm{SbTaO}_{4}$ having the rutile structure and the strong stereoactive character of $\mathrm{Sb}^{3+}$, deforming octahedral sites (see Ercit \& Foord 1995), suggest that the high contents of $\mathrm{Sb}_{2} \mathrm{O}_{3}$ found in ferrotapiolite (Lahti et al. 1983, Novák \& Černý 1998a, this work) probably reflect the presence of microscopic inclusions of a Sbrich mineral (primary stibiotantalite at Laštovičky), hidden below the polished surface of the analyzed spots. It

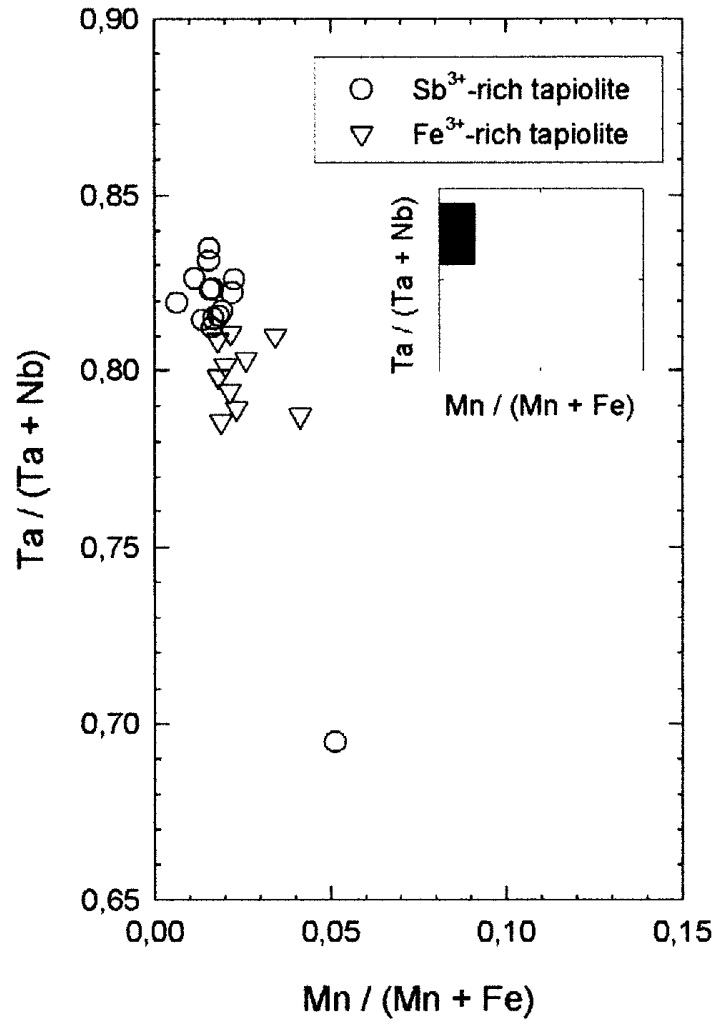

FIG. 5. The Laštovičky ferrotapiolite in the columbite quadrilateral (atom ratios). 

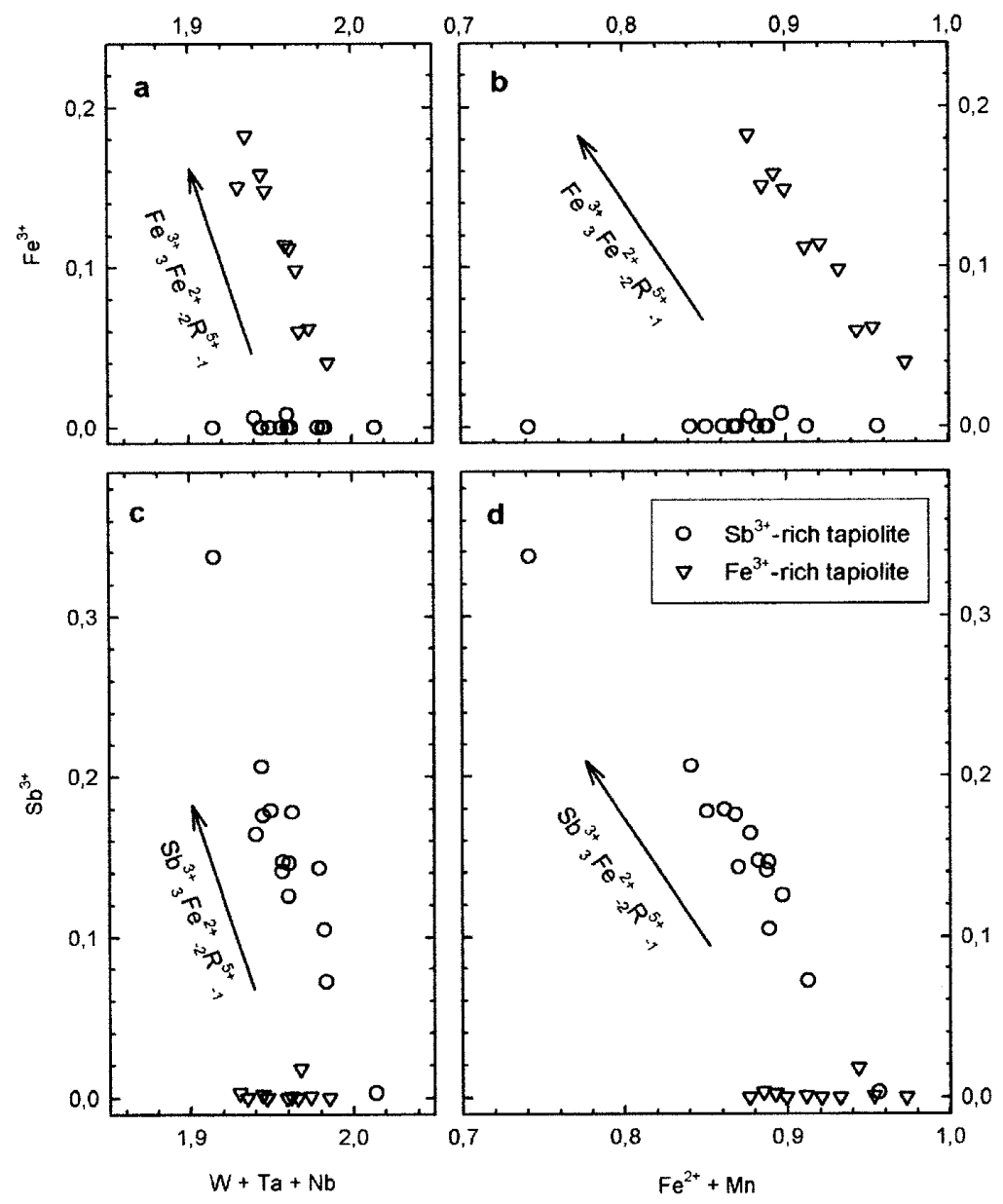

FIG. 6. Composition of the Laštovičky ferrotapiolite: a) $\mathrm{W}+\mathrm{Nb}+$ Ta versus $\mathrm{Fe}^{3+}$, b) $\mathrm{Fe}^{2+}$ $+\mathrm{Mn}$ versus $\mathrm{Fe}^{3+}$, c) $\mathrm{W}+\mathrm{Nb}+\mathrm{Ta}$ versus $\mathrm{Sb}^{3+}$, and d) $\mathrm{Fe}^{2+}+\mathrm{Mn}$ versus $\mathrm{Sb}^{3+}$. Substitution vectors: $\mathrm{Fe}^{3+}{ }_{3} \mathrm{Fe}^{2+}{ }_{-2} R^{5+}{ }_{-1}(\mathrm{a}, \mathrm{b}) ; \mathrm{Sb}^{3+}{ }_{3} \mathrm{Fe}^{2+}{ }_{-2} R^{5+}{ }_{-1}(\mathrm{c}, \mathrm{d})$, both leading to $M^{3+} \mathrm{TaO}_{4}$.

seems likely that $\mathrm{Sb}$ does not enter the ferrotapiolite structure, or if so, only in a minor quantity.

\section{Replacement process and mobility of Ta and $\mathrm{Nb}$}

Stibiotantalite is replaced by ferrotapiolite along irregularly distributed fractures (Fig. 2). Trace amounts of microlite minerals and cesstibtantite in pseudomorphs show initial low alkali content in altering fluids, followed by strong enrichment in iron. The textural relations between both major minerals and the host quartz or lepidolite suggest the following hypothetical reaction, assuming a constant amount of $(\mathrm{Ta}, \mathrm{Nb})$ and the complete removal of Sb from the system, because we did not find any relics of a secondary Sb-phase (e.g., valentinite or senarmontite) in the pores:

$$
\begin{aligned}
& 2 \mathrm{Sb}(\mathrm{Ta}, \mathrm{Nb}) \mathrm{O}_{4}+\mathrm{Fe}(\mathrm{OH})_{2}+2 \mathrm{H}_{2} \mathrm{O} \\
& =\mathrm{Fe}(\mathrm{Ta}, \mathrm{Nb})_{2} \mathrm{O}_{6}+2 \mathrm{Sb}(\mathrm{OH})_{3} .
\end{aligned}
$$

Because ferrotapiolite is the only replacement product observed, the reaction requires a $35 \%$ decrease of the volume occupied by the precursor. This value is in good agreement with the porosity of fresh, clay-mineral-free portions of the polished sections measured in the BSE image ( 28\%), but higher in weathered portions of ferrotapiolite with pores filled by clay minerals $(\sim 50 \%)$.

Textural relations and chemical composition indicate that this reaction represents an example of a dissolutionreprecipitation reaction [see Putnis (2002) and references therein], where pentavalent cations $\mathrm{Ta}$ and $\mathrm{Nb}$ are preserved in the system, but $\mathrm{Sb}$ is completely removed and $\mathrm{Fe}$ is incorporated into the structure of newly formed 
ferrotapiolite during the replacement. It involves reorganization of the $\mathrm{TaO}_{6}$ sheets of stibiotantalite (Černý $\&$ Ercit 1989) into the $\mathrm{TaO}_{6}$ framework octahedra in ferrotapiolite. The porosity estimates, which are in agreement with the above model, show that the mobility of $\mathrm{Ta}(\mathrm{Nb})$ in hydrothermal conditions at Laštovičky is low.

The textural pattern of replacement of primary stibiotantalite is similar to that observed in stibiotantalite replaced by microlite, manganotantalite and an undetermined $(\mathrm{Fe}>\mathrm{Mn}, \mathrm{Ta}>\mathrm{Nb})$ phase at Dobrá Voda, where a temperature of $\sim 500-350^{\circ} \mathrm{C}$ is suggested (Novák \& Černý 1998a). High but variable contents of $\mathrm{Fe}_{2} \mathrm{O}_{3}$ in ferrotapiolite ( $c f$. Wise \& Černý 1996), as monitored by a Mössbauer study and calculated from stoichiometry (see Figs. 3, 6) should indicate generally elevated $f\left(\mathrm{O}_{2}\right)$ during the alteration process; however, high variation in $\mathrm{Fe}_{2} \mathrm{O}_{3}$ suggests strong local variation in $f\left(\mathrm{O}_{2}\right)$. Consequently, the replacement of stibiotantalite by ferrotapiolite is a hydrothermal, fluid-induced, subsolidus process; however, we are not able to specify its $\mathrm{P}-\mathrm{T}-X$ conditions. The presence of cookeite and clay minerals in pores indicates that ferrotapiolite formation precedes the formation of such phyllosilicates and clay minerals in the pegmatite, although we do not know whether clay minerals in pores formed during low-temperature hydrothermal process or they were transported to pores during subsurface migration.

Another example of an alteration process similar to that of Laštovičky is provided by the intimate intergrowths of kimrobinsonite and cesstibtantite resulting from weathering of an unknown (Nb,Ta)-oxide mineral (possibly stibiotantalite or cesstibtantite; Nickel \& Robinson 1985). Its cryptocrystalline character and soft nature indicate porosity, although it is not mentioned by the authors. Assuming immobile $\mathrm{Ta}(\mathrm{Nb})$, the volume of these secondary assemblage would be decreased by approximately $30 \mathrm{vol} . \%$, considering both potential precursors (stibiotantalite or cesstibtantite).

\section{Element fractionation during hydrothermal alteration}

The simple assemblage stibiotantalite + ferrian ferrotapiolite is confined to the system $\mathrm{Ta}_{2} \mathrm{O}_{5}-\mathrm{Nb}_{2} \mathrm{O}_{5}-$ $\mathrm{Sb}_{2} \mathrm{O}_{3}-\mathrm{Fe}_{2} \mathrm{O}_{3}-\mathrm{FeO}$. Antimony and $\mathrm{Fe}$ are dominant cations at the $A$ sites, with mere traces of $\mathrm{Mn}, \mathrm{Ca}, \mathrm{Sb}$ and Cs (Table 1). Hence, the compositional evolution of late minerals in Laštovičky is relatively simple in contrast to possibilities that involve a wide spectrum of cations such as $\mathrm{Ca}, \mathrm{Na}, \mathrm{Sb}, \mathrm{Bi}, \mathrm{Cs}, \mathrm{Mn}, \mathrm{Fe}, \mathrm{Pb}, \mathrm{Ba}, \mathrm{K}, \mathrm{Sr}$, Sn, and $\mathrm{U}$ commonly participating during late hydrothermal alteration of stibiotantalite or other primary (Nb,Ta)-oxide minerals such as simpsonite or microlite (e.g., Černý \& Harris 1973, Foord \& Mrose 1978, Nickel \& Robinson 1985, Ercit 1986, Groat et al. 1987, Voloshin \& Pakhomovskyi 1988, Uher et al. 1998, Novák \& Černý 1998a). Trace amounts of microlitesubgroup minerals and cesstibtantite in pseudomorphs suggest initially elevated alkali contents in the fluid phase, followed by strong enrichment in iron. This trend is in agreement with replacement processes affecting primary $(\mathrm{Nb}, \mathrm{Ta})$-oxide minerals in granitic pegmatites from the Moldanubicum (e.g., Dobrá Voda; Novák \& Černý 1998a).

The elements at the $B$ site of stibiotantalite include $\mathrm{Ta}$ and $\mathrm{Nb}$, besides minor $\mathrm{Fe}^{3+}$ and perhaps $\mathrm{Fe}^{2+}$, and traces of $\mathrm{W}$ and $\mathrm{Ti}$ that are considered to enter this site. The stibiotantalite crystals exhibit a simple zonal pattern with an increase in $\mathrm{Ta} /(\mathrm{Ta}+\mathrm{Nb})$ from core to rim. The variability in $\mathrm{Ta} /(\mathrm{Ta}+\mathrm{Nb})$ of the parent stibiotantalite is reflected in that of secondary ferrotapiolite. Closely adjacent analyzed spots along contacts of stibiotantalite and ferrotapiolite yielded largely equal, or exceptionally very slightly decreased $\mathrm{Ta} /(\mathrm{Ta}+\mathrm{Nb})$ values in the secondary ferrotapiolite.

Iron enrichment during late stages of pegmatite crystallization (late magmatic to early subsolidus) has been recorded at some localities, especially in tourmaline (Foord 1976, Zagorskyi \& Peretyazhko 1992, Dutrow \& Henry 2000, Novák \& Taylor 2000) and rarely in micas (Novák \& Černý 1998b). However, only a few data have been published about the subsolidus behavior of $\mathrm{Mn}$ and $\mathrm{Fe}$ in $(\mathrm{Nb}, \mathrm{Ta}$ )-oxide minerals. An increase of $\mathrm{Fe}$ was described in alteration products of simpsonite (Ercit 1986), in manganotantalite replaced by ferrotantalite from the Rubikon pegmatite, Namibia (Baldwin 1989), in holtite replaced by ferrotapiolite (Voloshin \& Pakhomovskyi 1988), in products of replacement of stibiotantalite from the Moldanubicum, Czech Republic (Novák \& Černý 1998a), and in secondary ferrocolumbite after primary manganocolumbite at Rošná, Czech Republic (Novák \& Cerný 2001). However, the strong dominance of Fe over other elements, as was found at Laštovičky, is exceptional.

\section{Implications to fractionation of $\mathrm{Nb}$ from $\mathrm{Ta}$ in the crust}

Values of $\mathrm{Ta} /(\mathrm{Ta}+\mathrm{Nb})$ are typically found to be equal in the products of replacement of primary minerals such as stibiotantalite, simpsonite, manganocolumbite (Černý \& Ercit 1985, 1989, Ercit 1986, Ercit et al. 1986, Novák \& Černý 1998a, 2001, Smeds et al. 1999, Černý et al. 2004), and they were also retained in pyrochlore-group minerals during geochemical alterations (Lumpkin \& Ewing 1992, 1995). Uher et al. (1998) and Baldwin (1989) are the only authors to have described minor changes in $\mathrm{Ta} /(\mathrm{Ta}+\mathrm{Nb})$ between primary and secondary phases.

The secondary phases formed during various stages of hydrothermal alteration, from early subsolidus at $\mathrm{T}$ $\approx 500^{\circ} \mathrm{C}$ to near-surface weathering (Nickel \& Robinson 1985, Novák \& Černý 1998a). The low mobility of both $\mathrm{Nb}$ and Ta is suggested, even over distances of $<1 \mathrm{~mm}$, and thus preserve the $\mathrm{Ta} /(\mathrm{Ta}+\mathrm{Nb})$ values of the precursors in the alteration products. Thus subsolidus 
alteration does not affect the apparent degree of fractionation of Ta versus $\mathrm{Nb}$ attained during primary magmatic crystallization in granitic pegmatites.

The constancy of $\mathrm{Ta} /(\mathrm{Ta}+\mathrm{Nb})$ from primary minerals to their subsolidus alteration products in both initial alkali-rich and late alkali-poor conditions and in variable $\mathrm{P}-\mathrm{T}$ conditions from early subsolidus to near-surface weathering is a typical feature of rare-element granitic pegmatites (e.g., Ercit 1986, Novák \& Černý 1998a, 2001, Černý et al. 2004, this work). Consequently, fluid-induced fractionation of $\mathrm{Ta}$ from $\mathrm{Nb}$ seems to be negligible in granitic pegmatites. It corroborates experimental work of London et al. (1989) with Macusani glass, which revealed that the fractionation in a peraluminous granitic system rich in volatiles is significantly suppressed during the subsolidus hydrothermal stage. It also suggests the low solubility of (Nb,Ta)-oxide minerals in aqueous conditions (Wood 2004).

The ratio $\mathrm{Nb} / \mathrm{Ta}$ is widely used as an indicator of fractionation chiefly in magmatic rocks [e.g., Linnen \& Keppler (1997) and references therein]. Green (1995) suggested that the fluid/melt fractionation of $\mathrm{Nb}$ versus $\mathrm{Ta}$ in granitic pegmatites, with preference for $\mathrm{Ta}$ in the fluid, is the principal mechanism in crustal evolution. On the basis of a study of peraluminous granitic rocks from Nova Scotia, Dostal \& Chaterjee (2000) considered differences in the $\mathrm{Nb} / \mathrm{Ta}$ and $\mathrm{Zr} / \mathrm{Hf}$ due to a fluidremoval mechanism, which decreased the $\mathrm{Nb} / \mathrm{Ta}$ ratio in rocks (see also Hu et al. 1984). This contradicts the absence of hydrothermal (fluid) fractionation of Ta from $\mathrm{Nb}$ found in ferrotapiolite from Laštovičky (this work) and in other $(\mathrm{Nb}, \mathrm{Ta})$-oxide minerals from granitic pegmatites (e.g., Ercit 1986, Novák \& Černý 1998a) and supports the interpretation of Linnen \& Keppler (1997), who considered fractionation in melts sufficient to explain the low $\mathrm{Nb} / \mathrm{Ta}$ value in the continental crust.

\section{ACKNOWLEDGEMENTS}

Part of the laboratory work was done during the first author's tenure of a Postdoctoral Fellowship, awarded by the Faculty of Science, University of Manitoba. This work was also supported by Grant No. A3046002 from the Grant Agency of Academy of Sciences, Czech Republic to MN and VŠ, Grant RK99P03OMG014 to MN and JC, and by the Natural Sciences and Engeneering Research Council of Canada Major Installation, Major Equipment, Infrastructure and Research Grants to P. Černý and F.C. Hawthorne (University of Manitoba). The authors thank O. Schneeweiss for assistance in the Mössbauer study, and J. Staněk for comments on an early version of the manuscript. The reviews by T.S. Ercit and Ru Cheng Wang and the editorial improvements by Robert F. Martin are gratefully acknowledged.

\section{REFERENCES}

BALDWIN, J.R. (1989): Replacement phenomena in tantalum minerals from rare-metal pegmatites in South Africa and Namibia. Mineral. Mag. 53, 571-581.

Berlepsch, P., Armbruster, T., Brugger, J., Criddle, A.J. \& GRAESER, S. (2003): Tripuhyite, $\mathrm{FeSbO}_{4}$, revisited. Mineral. Mag. 67, 31-46.

ČernY, P., Chapman, R., Ferreira, K. \& Smeds, S.-A. (2004): Geochemistry of oxide minerals of $\mathrm{Nb}, \mathrm{Ta}, \mathrm{Sn}$ and $\mathrm{Sb}$ in the Varuträsk granitic pegmatite, Sweden: the case of an "anomalous" columbite-tantalite trend. Am. Mineral. 89, 505-518.

\& ERCIT, T.S. (1985): Some recent advances in the mineralogy and geochemistry of $\mathrm{Nb}$ and $\mathrm{Ta}$ in rare-element granitic pegmatites. Bull. Minéral. 108, 499-532.

$\&$

(1989): Mineralogy of niobium and tantalum: crystal chemical relationships, paragenetic aspects and their economic implications. In Lanthanides, Tantalum and Niobium (P. Möller, P. Cerný \& F. Saupé, eds.). Springer-Verlag, Heidelberg, Germany (27-79).

\& Wise, M.A. (1992): The tantalitetapiolite gap: natural assemblages versus experimental data. Can. Mineral. 30, 587-596.

\& HARRIS, D.C. (1973): Tapiolite, stibiotantalite and antimonian microlite from the Odd West pegmatite, southeastern Manitoba. Can. Mineral. 12, 76-78.

Dostal, J. \& ChaterJeE, A.K. (2000): Contrasting behaviour of $\mathrm{Nb} / \mathrm{Ta}$ and $\mathrm{Zr} / \mathrm{Hf}$ ratios in a peraluminous granitic pluton (Nova Scotia, Canada). Chem. Geol. 163, 207-218.

DudA, J. (1986): Pegmatites in the Bory granulite massif. Sbor. geol. Věd, Ložisk. geol. mineral. 27, 157-202 (in Czech with English summary).

Dutrow, B.L. \& HENRY, D.J. (2000): Complexly zoned fibrous tourmaline, Cruzeiro mine, Minas Gerais, Brazil: a record of evolving magmatic and hydrothermal fluids. Can. Mineral. 38, 131-143.

ERCIT, T.S. (1986): The Simpsonite Paragenesis. The Crystal Chemistry and Geochemistry of Extreme Ta Fractionation. Ph.D. thesis, Univ. Manitoba, Winnipeg, Manitoba.

, ČERNÝ, P. \& HAwTHORNE, F.C. (1993): Cesstibtantite; a geologic introduction to the inverse pyrochlores. Mineral. Petrol. 48, 235-255.

\& FooRD, E.E. (1995): Structural crystallography of the stibiotantalite group: a compositionally-dependent ferroelectric phase transition. Geol. Assoc. Can. - Mineral. Assoc. Can., Program Abstr. 20, A-29. 
HAwTHORNe, F.C. \& ČERnY, P. (1986): Parabariomicrolite, a new species, and its structural relationship to the pyrochlore group. Can. Mineral. 24, 655-663.

FooRD, E.E. (1976): Mineralogy and Petrogenesis of Layered Pegmatite-Aplite Dikes in the Mesa Grande District, San Diego County, California. Ph.D. thesis, Stanford University, Stanford, California.

\& Mrose, M.E. (1978): Rynersonite, $\mathrm{Ca}(\mathrm{Ta}, \mathrm{Nb})_{2} \mathrm{O}_{6}$, a new mineral from San Diego County, California. Am. Mineral. 63, 709-714.

GREEN, T.H. (1995): Significance of Nb/Ta as an indicator of geochemical processes in the crust-mantle system. Chem. Geol. 120, 347-359.

GROAT, L.A., ČERNÝ, P. \& ERCIT, T.S. (1987): Re-instatement of stibiomicrolite as a valid species. Geol. Fören. Stockholm Förh. 109, 105-109.

Hu, Shouxi, Sun, Mingzhi, Yan, Zhengfu, Xu, Jinfang, CAO, XiAOYUn \& Ye, Ying (1984): An important metallogenetic model for W, Sn and rare granitophile element ore deposits related to metasomatically altered granites. In Geology of Granites and Their Metallogenetic Relations. (Xu Keqin \& Tu Gianchi, eds.). Science Press, Beijing, People's Republic of China (519-537).

Kinast, E.J., ZaWislaK, L.I., DA CUNHA, J.B.M., ANTONIETTI, V., De VAsconcellos, M.A.Z. \& dos SANTOS, C.A. (2002): Coexistence of rutile and trirutile phases in natural tapiolite sample. J. Solid State Chem. 163, 218-223.

LAhti, S.I., Johanson, B. \& ViRkKUnen, M. (1983): Contribution to the chemistry of tapiolite - manganotapiolite, a new mineral. Bull. Geol. Soc. Finland 55, 101-109.

LinNEN, R.L. \& KePPLER, H. (1997): Columbite solubility in granitic melts: consequences for the enrichment and fractionation of $\mathrm{Nb}$ and $\mathrm{Ta}$ in the Earth's crust. Contrib. Mineral. Petrol. 128, 213-227.

London, D., Morgan, G.B., VI \& Hervig, R.L. (1989): Vapor-undersaturated experiments with Macusani glass + $\mathrm{H}_{2} \mathrm{O}$ at $200 \mathrm{MPa}$, and internal differentiation of granitic pegmatites. Contrib. Mineral. Petrol. 102, 1-17.

LUMPKIN, G.R. \& EwING, R.C. (1992): Geochemical alteration of pyrochlore group minerals: microlite subgroup. Am. Mineral. 77, 179-188.

$$
\&
$$

(1995): Geochemical alteration of pyrochlore group minerals: pyrochlore subgroup. Am. Mineral. 80, 732-743.

NiCKel, E.H. \& Robinson, B.W. (1985): Kimrobinsonite, a new tantalum mineral from Western Australia, and its association with cesstibtantite. Can. Mineral. 23, 573-576.

NovÁK, M. \& ČERNÝ, P. (1998a): Niobium-tantalum oxide minerals from complex granitic pegmatites in the Moldanubicum, Czech Republic: primary versus secondary compositional trends. Can. Mineral. 36, 659-672.
\&

(1998b): Abundance and franctionation trends of $\mathrm{Rb}$ and $\mathrm{Cs}$ in micas from lepidolite- and elbaite-subtype pegmatites in the Moldanubicum, Czech Republic. Acta Univ. Carol., Geol. 42, 86-90.

\& (2001): Distinctive compositional trends in columbite-tantalite from two segments of the lepidolite pegmatite at Rožná, western Moravia, Czech Republic. J. Czech Geol. Soc. 46, 1-8.

ČECH, F. \& STANĚK, J. (1992): Granitic pegmatites in the territory of the Bohemian and Moravian Moldanubicum. In Proc. International Symposium on Mineralogy, Petrology and Geochemistry of Granitic Pegmatites, Lepidolite 2000 (Nové Město na Moravě), 11-20.

\& StaněK, J. (1999): Lepidolite pegmatite from Dobrá Voda, near Velke Mezirici, western Moravia. Acta Mus. Moraviae, Sci. geol. 84, 3-44 (in Czech with English summary).

\& Šrein, V. (1999): Niobian cesstibtantite from the Dobrá Voda lepidolite pegmatite, western Moravia, Czech Republic. Neues Jahrb. Mineral., Monatsh., 354-360.

\& TAYLOR, M.C. (2000): Foitite: formation during late stages of evolution of complex pegmatites at Dobrá Voda, Czech Republic, and Pala, California, U.S.A. Can. Mineral. 38, 1399-1408.

Pouchou, J.L. \& Pichoir, F. (1984): A new model for quantitative analysis. I. Application to the analysis of homogeneous samples. La Recherche Aérosp. 3, 13-38.

$\&$ (1985): "PAP" procedure for improved quantitative microanalysis. Microbeam Analysis 20, 104105.

PUTNIS, A. (2002): Mineral replacement reactions: from macroscopic observations to microscopic mechanisms. Mineral. Mag. 66, 689-708.

Selway, J.B., Novák, M., Černý, P. \& Hawthorne, F.C. (1999): Compositional evolution of tourmaline in lepidolite-subtype pegmatites. Eur. J. Mineral. 11, 569-584.

Smeds, S.-A., ČernY, P. \& Chapman, R. (1999): Niobian calciotantite and plumbian-stannoan cesstibtantite from the Island of Üto, Stockholm Archipelago, Sweden. Can. Mineral. 37, 665-672.

STANĚK, J. (1973): Mineral paragenesis of the new lithiumbearing pegmatite at Laštovičky, western Moravia, Czechoslovakia. Scripta Nat. Fac. UJEP 1(3), 1-14.

Uher, P., Černý, P., Chapman, R., Határ, F. \& Miko, O. (1998): Evolution of Nb,Ta-oxide minerals in the Prašivá granitic pegmatites, Slovakia. II. External hydrothermal $\mathrm{Pb}, \mathrm{Sb}$ overprint. Can. Mineral. 36, 535-545.

Voloshin, A.V., Menshikov, Yu.P., Pakhomovskyi, Ya.A. \& Poleznayeva, L.I. (1981): Cesstibtantite (Cs,Na) $\mathrm{SbTa}_{4} \mathrm{O}_{12}$ - a new mineral from granitic pegmatites. Int. Geol. Rev. 24, 843-848. 
\& PAKHOMOVSKYI, YA.A. (1983): Mineral phases of aluminum-tantalum in rare-element pegmatites. Zap. Vses. Mineral. Obshchest. 112, 67-76 (in Russ.).

$$
\&
$$

(1988): Mineralogy of Tantalum and Niobium in Rare-Element Pegmatites. Nauka, Leningrad, Russia (in Russ.).

VON KNORRING, O. \& FADIPE, A. (1981): On the mineralogy and geochemistry of niobium and tantalum in some granite pegmatites and alkali granites of Africa. Bull. Minéral. 104, 496-507.

\& SAHAMA, T.G. (1979): A note on rynersonite from Uganda. Schweiz. Mineral. Petrogr. Mitt. 59, 15-18.

Wang, Ru Cheng, Fontan, F., Xu, Shi Jin, Chen, Xiao Ming \& Monchoux, P. (1997): The association of columbite, tantalite and tapiolite in the Suzhou granite, China. Can. Mineral. 35, 699-706.

WiSE, M.A. \& ČERNÝ, P. (1996): The crystal chemistry of the tapiolite series. Can. Mineral. 34, 631-647.

WooD, S.A. (2004): The aqueous geochemistry of zirconium, hafnium, niobium and tantalum. In Rare-Element Geochemistry and Ore Deposits (R.L. Linnen \& I.M. Samson, eds.). Geol. Assoc. Can., Short Course Notes 17, 329-407.

Zagorskyi, V.E. \& Peretyazhoo, I.C. (1992): Pegmatites with Gemstones of Central Transbaikalia. Nauka, Novosibirsk, Russia (in Russ.).

Received August 24, 2003, revised manuscript accepted June 28, 2004. 